\title{
Measures Affecting the Cross-Border Supply of Gambling and Betting Services (DS 285)
}

\author{
DOUGLAS A. IR WIN \\ Dartmouth College \\ JOSEPH WEILER \\ New York University
}

\begin{abstract}
The controversial gambling decision of the Appellate Body is mostly important because of examination of the nature of Access under Article XVI GATS, the relationship of that Article to Articles XIV and XVII GATS, and the parallels with Articles III, XI, and XX GATT. Notably, the Appellate Body took the position that an apparant internal regulatory measure, which, nonetheless, had equivalent effect to a zero quota, violated Article XVI GATS. A similar measure in the area of goods would have been examined under Article III GATT and require a showing of discrimination. The facts of the case would have allowed the decision to be based on Article XVII GATS. Most of this paper deals with this issue. We agree with this interpretation of Article XVI by the Appellate Body but are critical of its hermeneutics, suffering from a textual fetish and a policy phobia. Some other elements in the decision are also examined critically.
\end{abstract}

In the US-Gambling dispute, Antigua and Barbuda (Antigua) challenged a number of provisions of United States Federal and State law, notably the Wire Act, the Travel Act, and the Illegal Gambling Business Act, ${ }^{1}$ which, according to Antigua, amounted to an effective ban on Internet gambling. This, it was alleged, effectively shut out Antiguan service providers in a sector in relation to which the United States had, in its Schedule, given a commitment namely 'recreational, cultural, and sporting services' in violation of, notably, Article XVI GATS.

The United States denied that it had made such a commitment, and argued that even if it had given such a commitment, the internal measures in question were origin neutral and of a regulatory nature and therefore did not violate its access commitments under Article XVI. It further argued that the measures in question were in furtherance of policies designed to protect 'public morals and public order' and were thus permitted under the General Exceptions ex Article XIV GATS. The United States maintained at all times that it did not discriminate between domestic- and foreign-service providers in enforcing the prohibition on Internet gambling. 
In November 2004, the WTO Panel ${ }^{2}$ ruled that the United States had made a specific commitment to open its market to gambling services and that on their face these measures did violate Article XVI. The Panel further held that they could have been justified under Article XIV but failed to satisfy some of the conditions, notably necessity of said Article by failure to engage in consultation.

The Appellate Body, in its April 2005 Report, ${ }^{3}$ largely affirmed the Panel's main findings, sometimes with alternative reasoning. Importantly, it rejected the Panel's finding on necessity ex Article XIV but held that the US failed under the chapeau of said Article since in certain instances within the US, notably horseracing, Internet and other remote forms of gambling were allowed.

The resulting dispute rulings, both of the Panel (as modified by the Appellate Body) and of the Appellate Body itself, were adopted by the Dispute Settlement Body. At the DSB meeting of 19 May 2005, the United States stated its intention to implement the DSB's recommendations and indicated that it would need a reasonable period of time to do so. As Antigua and the United States failed to agree on a reasonable time period for implementation in accordance with Article 21.3(b) of the DSU, on 6 June 2005 Antigua requested that the reasonable period of time be determined through binding arbitration pursuant to Article 21.3(c) of the DSU. On 19 August 2005, the Arbitrator circulated his Award to the Members, determining that the reasonable period of time for implementation was 11 months and 2 weeks from 20 April 2005, expiring on 3 April 2006. ${ }^{4}$ In an interesting twist, the United States then took the view that in fact the Appellate Body had not found that it was in violation but that it simply failed to 'prove' the necessity of its otherwise justified measures and thus had to do nothing in order to bring itself into compliance other than surmount that burden of proof. This argument was rejected by a 'Compliance Panel' established at the request of Antigua. ${ }^{5}$ The Panel Reported on 30 March 2007..$^{6}$ The United States decided not to appeal that decision but also announced that it would be withdrawing its commitment in this sector. ${ }^{7}$ The saga continues. In the language of the Report to the DSB:

On 21 June 2007, Antigua and Barbuda requested authorization from the DSB, pursuant to Article 22.2 of the DSU, to suspend the application to the United States of concessions and related obligations of Antigua and Barbuda under the GATS and the TRIPS Agreement. On 23 July 2007, the United States (i) objected to the level of suspension of concessions and obligations proposed by Antigua

2 WT/DS285/R, 10 November 2004.

$3 \mathrm{WT} / \mathrm{DS} 285 / \mathrm{AB} / \mathrm{R}, 7$ April 2005.

4 Arbitration under Article 21.3(c) of the Understanding on Rules and Procedures Governing the Settlement of Disputes, Award of the Arbitrator Claus-Dieter Ehlermann, WT/DS285/13, 19 August 2005 ; provided to the Chairman of the DSB, WT/DS285/14, 23 August 2005.

5 Recourse to Article 21.5 of the DSU by Antigua and Barbuda, Request for the Establishment of a Panel, WT/DS285/18, 7 July 2006.

6 WT/DS285/RW, 30 March 2007.

7 See, e.g., http://worldtradelaw.typepad.com/ielpblog/2007/05/developments_in.html or http://www. ntra.com/content .aspx?type $=$ pr\&id=25606. 
and Barbuda and (ii) claimed that Antigua and Barbuda's proposal does not follow the principles and procedures set forth in Article 22.3 of the DSU. At its meeting on 24 July 2007, the DSB agreed that the matter referred to by the United States be referred to arbitration. ${ }^{8}$

The Gambling case has far-reaching implications. The case was the first to deal with the Internet and e-commerce, and only the second case dealing with the GATS. Gambling is a heavily regulated activity in many countries, and these regulations often restrict the geographic domain of where gambling can take place (e.g., legal casinos in specified locations). There are two threats to these regulations. First, the Internet threatens to erode this geographic element of domestic regulation by giving consumers easy access to gambling opportunities offered by providers away from their own home. ${ }^{9}$ Second, the GATS may pose an obstacle to the use of domestic regulations to restrict Internet gambling. In the case of the United States, both of these factors were part of the impetus for the passage of the Unlawful Internet Gambling Enforcement Act (UIGEA) in October 2006. As regards the GATS, the case highlights areas where it would seem that the legal disciplines for the liberalization of services have a greater margin of uncertainty compared to the parallel discipline for goods under the GATT. Tariff classification is not without its difficulties, but these seem at times lesser than the interpretation of service commitments. Likewise, as we shall see, the relationship between Articles XI, III, and XX GATT also appears more determinate than that between parallel Articles XVI, XVII, and XIV.

To help our reader, we provide in edited form an annex with a synopsis of the case as developed by the DSB itself, the issues on appeal, and the conclusions and finding of the $\mathrm{AB}$.

\section{The background to the Appellate Body decision: some economic and political issues}

The economic issues are only tangentially related to the main stakes in the Gambling case, but we will discuss them first because it provides the background for some of the legal interpretation to follow.

While there is a gambling industry in the United States - indeed, one with gross revenues of nearly $\$ 80$ billion in 2003 - most of it arises from highly regulated commercial casinos, Native American casinos, and State lotteries (Kearney, 2005). However, the present case did not concern the legality of gambling, but the restrictions on the long-distance provision of gambling services. At issue in the

8 http://www.wto.org/english/tratop_e/dispu_e/cases_e/ds285_e.htm.

9 See Wilson (2003). Indeed, although on-line gambling is generally illegal in the country, the United States is the home to more gambling websites than any other country (in terms of registered domain names) that serve as forwarding sites to serve customers in other countries. 
dispute was the ability of Internet sites located in Antigua to accept bets from customers located in the United States. ${ }^{10}$

The ban on Internet gambling does not appear on its face to be designed as a disguised trade restriction to protect domestic interests because the US prohibitions in the Wire Act of 1961 predate the Internet by decades, i.e. US policy has been longstanding on the issue. The regulation of gambling is a State and Federal issue in the United States. Several States ban Internet gambling altogether, and several Federal laws restrict the use of the technology associated with Internet gambling. The relevant Federal laws were the Wire Act, the Travel Act, and the Illegal Gambling Business Act. The Wire Act of 1961 'prohibits the knowing use of any "wire communication facility" to transmit bets or wagers, use of information assisting betting or wagering on a sports event or contest, or any communication which entitles the recipient to receive money or credit resulting from betting or wagering'. ${ }^{11}$

\section{The nature of the US commitment}

The first major issue before the Panel was whether these State and Federal restrictions on Internet gambling violate US commitments under Article XVI of the GATS, which prohibit certain quantitative restrictions on market access. This raised the highly contested issue of what specific commitments the United States had agreed to in its GATS schedule. The US commitment is ambiguous because there is no line in the GATS schedule that explicitly mentions gambling and certainly not Internet gambling.

Antigua held that the United States did not indicate any restrictions on market access in its schedule of GATS commitments. The United States had indicated 'none' in terms of the limitations on market access under the heading of 'Other Recreational Services (except sporting)'. Antigua argued that 'other recreational services' covered gambling and that gambling was not 'sporting' in part on the basis of a document distributed by the GATT Secretariat during the Uruguay Round. The 1993 Services Sectoral Classification List, which in turn made reference to the United Nations' Provisional Central Product Classification, has two subcategories under 'Sporting and Recreational Services': 'Sporting Services' and 'Other Recreational Services'. The sub-subcategory 'Gambling and Betting Services' falls under the latter subcategory, i.e. not under

10 The dispute was initiated at the instigation of Jay Cohen, as US national and founder of World Sport Exchange, who had been sentenced to jail for selling gambling services to US citizens from Antigua. He convinced the Antigua authorities to bring a case against the United States in the WTO, raising the issue of the privatization of dispute settlement. It is, of course, quite common that powerful corporate interests are behind WTO disputes.

1118 USC 1084. It is unclear whether the Wire Act prohibits non-sports gambling, but the Department of Justice has interpreted it to cover all forms of gambling. As a result, any online gambling businesses located in the United States risks prosecution under the Wire Act. 
sporting services but under other recreational services. Although the document's classification scheme was a reference point only, and was not a legal and binding classification system, to the extent that this was used to frame most countries'

GATS commitments, this classification could be interpreted as implying that the United States had not made a commitment on sporting services but had made a commitment on gambling and betting services. Antigua argued that the United States made a full commitment for the cross-border supply of gambling and betting services.

The United States insisted that the classification list was never meant to bind Members to the definitions and that the list could not control the interpretation of the US schedule. Other countries had put gambling services in various sections (entertainment services, tourist services, etc.) of their GATS commitment schedule, and there was no single place where such a commitment was recognized. Thus, gambling and betting services could fall under 'sporting services', which had been excluded from the US commitment.

The problem, of course, is that the precise US commitment is ambiguous because there is no explicit commitment statement; the US schedule is silent on the issue of gambling, so the question turns on which category of services gambling is believed to fall under. Both the Panel and the Appellate Body sided with Antigua in holding that gambling and betting services were covered by the GATS schedule of the United States and decided this issue by referring to the relevant schedule of US services commitments with respect to 'other recreational services (except sporting)'. The Appellate Body agreed that the US commitment did not exclude gambling services by the exclusion of 'sporting'.

The Panel recognized that the failure to exclude gambling may have been an oversight by US negotiators at the Uruguay Round, noting (7.3):

the United States may well have inadvertently undertaken specific commitments on gambling and betting services. However, it is not for the Panel to second-guess the intentions of the United States at the time the commitment was scheduled. Rather, our role is to interpret and apply the GATS in light of the facts and evidence before us.

Indeed, given the predominant jurisdiction of the US States in gambling matters and the existing State restrictions, it would have been odd for US negotiators to have signed on to a commitment to open markets in gambling services, although these were negotiated before the Internet had begun to flourish.

Even though it was found to have made a GATS commitment to provide market access in gambling services and that several of its measures denied such access, the United States could (and did) invoke the 'General Exceptions' Article XIV of the GATS to justify its actions. Article XIV reads:

Subject to the requirement that such measures are not applied in a manner which would constitute a means of arbitrary or unjustifiable discrimination between 
countries where like conditions prevail, or a disguised restriction on trade in services, nothing in this Agreement shall be construed to prevent the adoption or enforcement by any Member of measures:

(a) necessary to protect public morals or to maintain public order;

(c) necessary to secure compliance with laws or regulations which are not inconsistent with the provisions of this Agreement including those relating to:

(i) the prevention of deceptive and fraudulent practices or to deal with the effects of a default on services contracts.

This was the first WTO Panel to consider a dispute that involved these provisions in the GATS.

The United States argued that the restrictions on Internet gambling were necessary to prevent minors, who are generally forbidden from gambling, from accessing gambling websites and to prevent money laundering by organized crime. The gambling industry has always had a disreputable aspect to it and economists have identified some of the negative externalities associated with sites that have legal gambling, particularly in terms of crime and other community costs (Grinols and Mustard, 2006). In terms of the public-welfare justification for the Internet ban, the costs of Internet gambling, in particular, have not been as well documented, but the Panel and Appellate Body had little difficulty accepting the publicmorals exception claimed by the United States.

The Panel set forth a two-part test to determine if this provision was met. As it stated (6.455):

in determining whether a challenged measure is provisionally justified under that

Article, the Member invoking that provision must demonstrate two elements, namely:

(a) the measure must be one designed to 'protect public morals' or to 'maintain public order'; and

(b) the measure for which justification is claimed must be 'necessary' to protect public morals or to maintain public order.

The Panel decided affirmatively with respect to (a). They agreed with the United States that issues related to public order and morals - such as fraud, underage gambling, and organized crime - were specifically related to the remote provision of gambling services that justified the regulations.

However, Antigua maintained that it could have addressed the US concerns if the United States had been willing to consult or negotiate an agreeable outcome. Because the United States refused to consult or negotiate, the Panel decided that the US laws were not 'necessary' to enforce the Article XIV(a) exception. As they explained $(6.533,6.534)$ :

while the United States has legitimate specific concerns with respect to money laundering, fraud, health and underage gambling that are specific to the remote 
supply of gambling and betting services, which suggests that the measures in question are 'necessary' within the meaning of Article XIV(a), the United States has declined Antigua's invitation to engage in bilateral and/or multilateral consultations and/or negotiations to determine whether there is a way of addressing its concerns in a WTO-consistent manner.

... given the circumstance of this case and for the reasons explained above ... the United States, before imposing a WTO inconsistent measure, was obliged to explore these options in a good faith manner with a view to exhausting WTOconsistent alternatives, even if it considered that the measures in question were 'indispensable'.

Thus, the Panel (6.526) stated:

The United States' obligation to consult with Antigua before and while imposing its prohibition on the cross-border supply of gambling and betting services derives from the fact that it has undertaken a specific market access commitment for mode $1 \ldots$ In rejecting Antigua's invitation to engage in bilateral or multilateral consultations and/or negotiations, the United States failed to pursue in good faith a course of action that could have been used by it to explore the possibility of finding a reasonably available WTO-consistent alternative.

The Panel also found that the United States had not satisfied the conditions required by the chapeau of Article XIV, which reads: 'Subject to the requirement that such measures are not applied in a manner which would constitute a means of arbitrary or unjustifiable discrimination between countries where like conditions prevail, or a disguised restriction on trade in services, nothing in this Agreement shall be construed to prevent the adoption or enforcement by any Member of measures.' The Panel noted that: 'The chapeau requires that the measures in question are not applied in a manner that would constitute a means of arbitrary or unjustifiable discrimination between countries where like conditions prevail, or a disguised restriction on trade in services.'

The Panel found that the United States acted inconsistently with the chapeau in negotiating with some Members but not others and also selectively enforcing the Internet ban against domestic suppliers. In particular, the Internet Horseracing Act permits the remote supply of gambling and betting services for horse races. The Panel (6.607) found that the United States failed to show 'that it applies its prohibition on the remote supply of these services in a consistent manner as between those supplied domestically and those that are supplied from other members'.

The Appellate Body overruled the Panel's finding on Consultation as well as its ruling that inconclusive evidence of differential enforcement was evidence of discrimination in violation of the chapeau, but upheld the finding of discrimination (369) 'solely to the possibility that the [Interstate Horseracing Act] exempts only 
domestic suppliers of remote betting services for horse racing from the prohibitions in the Wire Act'.

The Panel and Appellate Body regarded the Interstate Horseracing Act as inconsistent because it allows Internet gambling on horseracing, but foreign websites are not authorized to participate. This would seem to put the United States in the awkward position of either allowing all Internet gambling or repealing the IHA, neither of which would have been attractive to Congress. ${ }^{12}$ Indeed, the IHA is subject to dispute. The Justice Department has taken the position that the 1961 Wire Act overrides the IHA, even though the IHA is a more recent statute, because neither statute expressly exempts IHA transactions from the Wire Act. The domestic horseracing industry strongly disagrees. The UIGEA of 2006 is carefully drafted to maintain the status quo regarding horseracing, preserving the ability of the Executive Branch and the horseracing industry to litigate the proper interpretation of these two statutes; the text of the bill states: 'It is the sense of Congress that this Act does not change which activities related to horse racing may or may not be allowed under Federal law.' Congress does not intend that the new enforcement tools be used against transactions that are apparently legal under IHA, but the Department of Justice could still attempt to prosecute a horseracing transaction under the Wire Act and test their interpretation in court.

Regardless of the decisions specifically related to this case, the ban on Internet gambling raises several interesting economic issues having to do with its enforcement and the regulation of information markets in general.

Given the open-access nature of the Internet, the United States faces significant jurisdictional and enforcement obstacles to maintaining a ban on the gambling of domestic citizens using offshore Internet sites (Clarke and Dempsey, 2001). As noted, the States, and not the Federal government, have a major authority to determine which activities are legal or not. The determination of which activities are legal or illegal often involves fine distinctions between specific actions. For example, in most States playing games on the Internet (poker, etc.) is not illegal, but the betting on those games is illegal. Because foreign-based gambling websites cannot be shut down, the enforcement approach has been to stop the financialtransactions payments. In 2001, major credit-card companies (Visa, Mastercard)

12 Congress passed the Interstate Horseracing Act (IHA) of 1978 to regulate interstate wagering on horseracing and to prevent States from interfering with the gambling policies of other States, thus affirming that States have primary responsibility for regulating gambling within their borders. In 2000, Congress amended the IHA to clarify that Internet technology could be used in the transmission of interstate off-track wagers, noting that the statute only regulates 'a legal wager placed or accepted in one State with respect to the outcome of a horserace taking place in another State ... where lawful in each State involved, placed or transmitted by an individual in one State via telephone or other electronic media and accepted by an off-track betting system in the same or another State' (15 U.S.C. $3002(3))$. Therefore, a wager on a horserace that violates any State law is not permitted under the IHA. 
and banks began refusing to make transactions with Internet gambling sites, but it is quite likely that these restrictions could be evaded through third parties, although this may impose a substantial cost on those attempting to gamble. ${ }^{13}$

A final issue is the broader regulation of information markets. Information markets allow trading in contracts that yield a payment based on the outcome of an uncertain future event. These markets allow trading in contracts on candidates in political elections (such as the Iowa electronic markets), futures contracts in terms of a firm's sales, commodities prices, etc. In some instances, the distinction between trades on these information markets and gambling is not at all clearcut. For example, does the trading of commodity futures constitute 'gambling' or is it something that serves a useful economic purpose by hedging risks? How about the trading of oil-price futures when it is not oil that will actually be traded, but rather payments based on the realization of one's expectations of the future price of oil ? What about payments related to the outcome of a presidential election? In some of these cases, there may be a fine line between 'gambling' and those that elicit information that is useful for firms or traders.

Although the Commodities Futures Trading Commission has some regulatory authority in this area, the current regulatory structure is dominated by State and Federal laws that regulate Internet trading. Hahn and Tetlock (2006) propose that there be Federal laws that allow the Commodities Futures Trading Commission to establish an 'economic purpose' test to allow information-market contracts that provide financial hedging opportunities or information that improves economic decision making.

13 Indeed, the Unlawful Internet Gambling Enforcement Act of 2006 is an enforcement measure that does not explicitly ban Internet gambling. The Federal government does not have the jurisdiction to ban within-State Internet gambling, a determination that is reserved for the States. But the legislation seeks to prohibit the 'acceptance of any financial instrument for unlawful internet gambling', where it is up to the States to determine what constitutes 'unlawful' Internet gambling. The law attempts to restrict the mechanisms linked to the funding of such gambling, such as by shutting down the use of electronic funds transfers involved in unlawful gambling.

Sec. 5363. Prohibition on acceptance of any financial instrument for unlawful internet gambling:

No person engaged in the business of betting or wagering may knowingly accept, in connection with the participation of another person in unlawful Internet gambling -

(1) credit, or the proceeds of credit, extended to or on behalf of such other person (including credit extended through the use of a credit card);

(2) an electronic fund transfer, or funds transmitted by or through a money transmitting business, or the proceeds of an electronic fund transfer or money transmitting service, from or on behalf of such other person;

(3) any check, draft, or similar instrument which is drawn by or on behalf of such other person and is drawn on or payable at or through any financial institution; or

(4) the proceeds of any other form of financial transaction, as the Secretary and the Board of Governors of the Federal Reserve System may jointly prescribe by regulation, which involves a financial institution as a payor or financial intermediary on behalf of or for the benefit of such other person. 
Clearly, even in the absence of the WTO case, US regulatory authorities would face an abundance of challenges in trying to limit Internet gambling because of the nature of the technology and the difficulties of enforcement.

\section{The Appellate Body Report - some critical reflections}

Doctrinally, given that this Report is only the second AB Report on the GATS and the first to deal directly with 'cyberspace and trade' it may be thought to be of significant importance in a field that no doubt will yield future disputes and will be mined with that future prospect in mind. However, given the conceptual and linguistic proximity of certain provisions of the GATT and the GATS, notably Articles XX and XIV respectively, the doctrinal significance of some aspects of the case are not limited to Services and Cyberspace.

Beyond doctrine, we consider it as an example a self-identity tension in the self understanding of the Appellate Body. On the one hand, it is a demonstration of a more mature and self-assured Appellate Body, consolidating a richer and more nuanced voice in the application of the DSU and understanding its role as not only determining appeals but also as largely in charge of a delicate and difficult disputesettlement process. Thus, the Report is attentive to the structural asymmetries between the ad hoc Panels and the permanent Appellate Body and far more sensitive to the importance of a constructive relationship within these two columns of the 'judicial' dispute-settlement system. ${ }^{14}$ In the judicial approach, the Report is more laconic and incremental, matter of fact (as well as 'matter of law') rather than 'formulaic'15 and didactic. The Appellate Body in this Report is notable in its willingness to leave things 'to another day', ${ }^{16}$ to resist the temptation of 'completing the analysis', and thus, on occasion dramatically, making the Parties responsible for the outcome of cases. It struck down, a titre juste in our view, review of a large number of US State measures on the grounds that Antigua had not in its Statement of Claim and pleadings discharged the relatively low threshold of making a prima facie case of violation - a case that could have easily been made on the basis of data within the briefs themselves. Likewise, in addressing the requirement of necessity in relation to Article XIV GATS, the implicit rebuke was not, as often in the past, to the Panel but to deficient lawyering. The judicial quality of WTO dispute settlement ultimately will depend on each element in the process - parties, Panels, and the AB itself - operating at a high level and with a clear understanding of their respective, oftentimes nonfungible roles. Gambling in this respect is another illustration of an $\mathrm{AB}$ that understands its role to be the husbanding of the system itself and not just the settlement of a specific dispute.

14 See generally Voon (2006).

15 The arresting analysis of Nagel in Nagel (1985) should be obligatory reading for all judges.

16 E.g., Recital 256. 
On the other hand, and in relation to the most fraught legal issue in the case, the Appellate Body reverts to its almost obsessive reliance on, as we shall seek to show, rather flimsy textualism and, at times, equally flimsy contextualism as the mainstay of its hermeneutics.

We do not propose to examine all aspects of the Appellate Body Report but instead to focus on a series of issues that, in our view, merit critical discussion.

\section{Violation of a WTO obligation by cumulative measures}

The first issue on appeal, seemingly trivial, was the question whether the Panel erred in finding that the 'total prohibition' on the cross-border supply of gambling and betting services alleged by Antigua was neither capable of constituting an autonomous measure that can be challenged in and of itself, nor identified as a measure in Antigua's request for the establishment of a panel.

The Appellate Body's analysis proceeds as follows. It draws a sharp distinction between measures and their 'effects.' (Recital 123): '[T]he "measure" must be the source of the alleged impairment, which is in turn the effect resulting from the existence or operation of the "measure", (Recital 121 -emphasis in original). And, "if the "total prohibition" were a measure, a complaining party could fulfil its obligation to identify the "specific measure at issue", pursuant to Article 6.2 of the DSU, merely by explicitly mentioning the "prohibition". Yet, without knowing the precise source of the "prohibition", a responding party would not be in a position to prepare adequately its defence, particularly where, as here, it is alleged that numerous Federal and State laws underlie the "total prohibition", (Recital 125).

It then concludes:

Therefore, we conclude that, without demonstrating the source of the prohibition, a complaining party may not challenge a 'total prohibition' as a 'measure', per se ... Accordingly, we uphold the Panel's finding ... that 'the alleged "total prohibition" on the cross-border supply of gambling and betting services describes the alleged effect of an imprecisely defined list of legislative provisions and other instruments and cannot constitute a single and autonomous "measure" that can be challenged in and of itself'. (Recital 126).

There is more doctrinal and policy significance to this holding than might meet the eyes. Clearly, it would seem that a single formal measure prohibiting or having the effect of so prohibiting cross-border supply of service would be caught: the measure and its effect would be one. But what if this were not the case?

The Panel holding is ambivalent: Does it turn on the fact that the list of legislative provisions and other instruments were imprecisely defined? Or because the total prohibition was the alleged 'effect' of such of that list? In other words, if the list was precisely rather than imprecisely defined, would the 'total prohibition' effect (if proven, of course) constitute a single and autonomous 'measure' that could be challenged in and of itself. This does not seem to be the case - since after all the Panel went ahead and constructed a very precise list of Federal and State measures, 
and yet it still did not consent to regard the potential total-prohibition effect of that precise list as constituting a challengeable measure.

There is a different ambiguity in the analysis of the Appellate Body. In the first part of its analysis (reproduced above), it would seem that if the total prohibition is the cumulative effect of several measures it cannot, in and of itself, be considered a challengeable measure. In its 'conclusion' it seems to change tack for here it states: 'Without demonstrating the source of the prohibition [etc.].' Does this not suggest that as long as the complaining party demonstrated the source creating an effect, such effect could be considered the measure to be challenged? But immediately afterwards the $\mathrm{AB}$ goes on to endorse the holding of the Panel, which suggests otherwise.

Why is this hair splitting of consequence? As Members become legally acculturated to WTO and GATT disciplines, they are much more careful not to adopt egregious border or other measures. The interesting case is, thus, a series of measures, each of which, in and of itself, does not amount to a full prohibition (or to understand the full significance of the point, each of which does not amount to a violation of a distinct GATT or GATS obligation) and which may include also 'soft' measures such as in Semiconductors ${ }^{17}$ but the cumulative effect of which, and only the cumulative effect of which, would bring about the impairment that the $\mathrm{AB}$ speaks of, an impairment that amounts to a violation of a specific obligation. ${ }^{18}$

We would like to suggest tentatively that even an 'effect' that violates an obligation can constitute a measure as long as, faithful to the formulation of the $\mathrm{AB}$ itself, the source of such an effect in other measures (which alone may not be violative) is demonstrated.

\section{The role of lawyers and panels in establishing and discharging} the duty of making a prima facie case

The AB struck down the Panel holding that Antigua had made a prima facie case in relation to the eight State measures. Indeed, prima facie, it would seem that the Panel process was curious:

151. In our view, certain general statements made by Antigua in its second written submission were insufficient to permit the Panel to proceed on the basis that Antigua had established a prima facie case regarding the eight State laws identified by the Panel. For example, Antigua's second written submission contains a general discussion of State gambling laws, with footnote citations to, inter alia, a report by the United States General Accounting Office and a law review article. ${ }^{173}$ The law review article contains a discussion of State regulation of gambling, with reference, primarily in footnotes, to the laws of several States, including California, Hawaii, Illinois, Louisiana, and South Dakota. As we understand it, the Panel followed this trail of footnote references, and then

17 Japan-Trade in Semiconductors, Panel Report of 24 March 1988. See: Porges, (1989).

$18 \mathrm{We}$ are not alluding here to nullification and impairment issues. 
compared the statutes cited in the footnotes of that law review article with Antigua's panel request to determine whether Antigua had identified provisions of those statutes and, thereby, to ascertain which State law Antigua intended to include as part of its claim. ${ }^{174}$ This led the Panel to conclude that certain laws of Louisiana and South Dakota were challenged by Antigua under Article XVI.

152. The Panel engaged in a similar multi-step analysis in seeking to discern some connection between the laws of Massachusetts, New Jersey, New York, and Utah, and Antigua's references in its written submissions and various exhibits. ${ }^{175}$ Yet we are unable to detect any connection, however tenuous, between the relevant laws of Colorado and Minnesota, on the one hand, and the allegation of inconsistency with Article XVI: 2, on the other hand. Although Antigua did submit these laws in its exhibits, we see no arguments in any submissions that would have clearly informed the Panel and the United States how those two laws would form part of Antigua's claims under Article XVI: 2(a) and XVI: 2(c). It follows that, without providing a stronger link between the particular State law being challenged and the obligation alleged to have been infringed, Antigua failed to make a prima facie case with respect to any of these eight State laws. (Footnotes omitted)

By contrast, the AB upheld the Panel in finding that Antigua had made a prima facie case in relation to the three Federal laws in question. But the $\mathrm{AB}$ reasoning is worth noting, and in particular Recital 148:

147. We begin our examination of the challenged measures with the three Federal laws, namely, the Wire Act, the Travel Act, and the IGBA. We observe that Antigua submitted the texts of these statutes and explained its understanding of them. In support of its argument that the three Federal statutes prohibited certain kinds of cross-border supply of gambling services, Antigua submitted to the Panel a report by the United States General Accounting Office on internet gambling, and a letter from a Deputy Assistant Attorney General of the Department of Justice informing an industry association of broadcasters that internet gambling violates the three Federal statutes. (footnotes omitted)

148. In addition, as we noted above, Antigua, in its second written submission, alleged the '[f]ederal laws' prohibiting cross-border supply to be inconsistent with Article XVI. The United States argues that Antigua never 'specifically alleged' the inconsistency of the three specific Federal statutes with Article XVI. Although, Antigua did not expressly mention these statutes by name when alleging inconsistency with Article XVI, we are of the view that, in the context of Antigua's previous statement clearly identifying these three statutes and the Panel's subsequent questioning on these particular measures, the reference to '[f]ederal laws' clearly covered the Wire Act, the Travel Act, and the IGBA. As a result, in our view, Antigua's arguments and evidence were sufficient to identify the Wire Act, the Travel Act, and the IGBA, and to make a prima facie case of their inconsistency with sub-paragraphs (a) and (c) of Article XVI: 2. (footnotes omitted) 
It is the intervention of the Panel's 'subsequent questioning' that merits attention. Is it not the case that had the Panel not 'subsequently intervened' the Federal measure prima facie case in relation to Article XVI would be weaker, perhaps inexistent? And is it not the case that had the Panel engaged in a bit of 'subsequent questioning' in relation to the State measures rather than follow the trail of footnotes, the nexus between the State measures and Article XVI would be equally clear?

Now, of course there is a difference between Panel questioning to which both parties may respond and the Panel proprio muto going on its own trail and drawing its own conclusions that were not informed by the adversarial process, but should the burden of making a prima facie case depend on the inclination of the Panel to engage in 'subsequent questioning'? Consistent with the overall approach in this Report should the $A B$ not have inquired whether, absent the questions and response of the Panel, the prima facie case also in relation to the Federal laws was in fact discharged by the Party?

Our purpose in raising this issue is not to nitpick; it actually raises two important and interrelated issues of process. In abstract, it raises the issue whether, in the interest of, say, ensuring equality of arms (and especially in a case in which a developing country is unsupported by rich multinationals) the Panel may 'complete the analysis' as it seemed to do in relation to the Federal laws and which the AB seemed to endorse. Or should such Panel 'activism' be considered as a violation of Article 11 DSU? And it also raises the question whether this question of principle should be influenced by the measure of substantive lacunae found, in say, the Statement of claim. The State of the art today is such, and this is confirmed also in this case itself, that the prima facie raff is very low. For the Panel to step in could be thought of not only as harmless error, but maybe a positive duty in the interest of justice. Both the question of inconsistency (State Measure - no subsequent questioning; Federal measure - subsequent questioning) and the role of the Panel in such a case remain unresolved. This, by contrast is not the situation in the latter parts of the Report where the AB highlighted Antigua's failure to discharge the alternative-measure burden under the 'necessary' requirement of Article XIV. ${ }^{19}$

\section{The USA commitment and its violation ex Article XVI: measures having an effect equivalent to quantitative restrictions}

These, in some respects, are the two principal planks on which the case rests. As regards the question of United States commitment, we do not find that we share some of the criticism leveled against the $\mathrm{AB}$ on its interpretative methodology. In fact, the decision and reasoning on this issue seem to us a useful correction of the unsatisfying LAN decision. ${ }^{20}$ In that case, the $\mathrm{AB}$ correctly stipulated, as it does

19 Recitals 266 et seq.

20 WTO Appellate Body Report, European Communities-Customs Classification of Certain Computer Equipment, AB-1998-2, WT/DS62, 67, 68/AB/R (98-2271). 
here, that a Schedule is to be interpreted as part of an agreement with both parties in mind as to its meaning. In LAN, the Panel failed to do so, relying instead on 'legitimate expectations' but, it is submitted, for unpersuasive reasons it concluded that the Panel's failure resulted in proof that the EU interpretation of the Schedule in that case was more persuasive than its adversary. In Gambling, the AB actually engages in an analysis which indicates that Antigua's interpretation had more hermeneutic pull than that of the US - notably in text leading to Recital 203. By contrast, on the issue of Article XVI we do not dispute the result but find the hermeneutics wanting. Potentially one of the most far-reaching legal implications of the Decision in Gambling concerns the application of Article XVI to originneutral measures that on their face do not apply directly to the provision of services by outside providers and may appear to be simply part of the regulatory matrix of a Member that have implications for the provision of services.

The US Wire $\mathrm{Act}^{21}$ provides, inter alia:

Whoever being engaged in the business of betting or wagering knowingly uses a wire communication facility for the transmission in interstate or foreign commerce of bets or wagers ... shall be fined ... or imprisoned not more than two years, or both.

The Panel had found that this US statute prohibited the use of at least one or potentially several means of delivery included in Mode 1 of services covered by Article XVI GATS, and that, critically, the Statute constituted a 'zero quota' for one or more or all of those means of delivery ${ }^{22}$ that were part of the US commitment in its schedule and thus amounted to a violation of Article XVI: (2)(a) and (b).

The Travel Act ${ }^{23}$ and the Illegal Gambling Business Act ${ }^{24}$ are drafted in equally origin-neutral language and were both interpreted by the Panel to amount to a similar 'zero quota'.

The United States argued, inter alia, in its Appeal that Article XVI: (2)(a) and (c), correctly interpreted, did not apply to the type of measures exemplified by the Wire Act, the Travel Act, and the Illegal Gambling Act.

On this issue, the AB confirmed both the Panel's interpretation of the GATS provisions and their application to the US Statute.

\section{Market access: 'Preliminary Matters ${ }^{25}$ or a 'Gaping Hole?'}

On the issue as to whether, in principle, Article XVI can apply to origin-neutral internal measures that may have the effect of producing a zero quota on the

21 Section 1084(a) of Title 18 of the US Code.

22 Panel Report 6.363.

23 Section 1952(a) and (b) of Title 18 of the US Code.

24 Section 1955 (a) and (b) of Title 18 of the US Code.

25 This is the title the $\mathrm{AB}$ gives its treatment of partial access - see Recitals 218 et seq. 
provision of services, we find ourselves in agreement with the controversial position $^{26}$ adopted by the Panel and the Appellate Body for reasons that we shall later explain. It is, however, far from certain whether the measures challenged in Gambling fall into this category. It is far from certain because of a failure to deal with an indispensable step in the legal reasoning, a step necessary before one may arrive at the conclusion that an origin-neutral regulatory measure having a 'zero effect' does in fact and in law violate Article XVI. Even if one takes the view, as did the Panel and the Appellate Body, that in principle such measures may violate Article XVI, there is a serious issue if such is the case if the effects of the measure are felt only 'on part of a scheduled sector' or if the measure in question restricts only one means of delivery covered by Mode 1, leaving others unaffected.

Imagine, for example, a hypothetical commitment to 'Internet gambling and betting services' by the US. Imagine further a hypothetical US Statute applicable both to domestic and foreign Internet gambling service providers that banned, for reasons of consumer protection, the placing of Internet bets and especially the paying for such bets without automatic encryption of consumer credit-card information by the service provider. Or an internal measure which required that the provider use software that was able to verify the age of Internet gamblers so as to ensure against gambling by minors, or even more challenging, prohibited Internet gambling through wireless access (because of the unknown health effect of extensive WiFi) but which allowed it over Internet wires. A nondomestic provider offering 'non encrypted Internet gambling' or 'unrestricted gambling' or using wireless services, could argue that such provisions amount to a 'zero quota' on his means of delivery or his segment of the market and were thus violative of Article XVI. The only redress of the United States in such a case would be to defend such measures as an exception provided by Article XIV. The Panel Decision seems to support such an interpretation.

One could also take the view that, even assuming the Commitment in the schedule covered Internet gambling, such (hypothetical) measures did not amount to a limitation contemplated by Article XVI. On this view, there is no violation of Article XVI since Internet gambling remains open to service providers as per the commitment, and what one has is simply origin-neutral legitimate regulation of the Internet pursuant to public policy. On this view, there is no 'zero quota' of the relevant service market, which is Internet gambling in its totality. The measures do not 'zero quota' the provision of services thus understood, even if they might shut out the market to a provider who refused to use encryption or use software that could be used to verify the age of gamblers if the law so required or insisted on using WiFi. On this view, provided the United States did not violate the distinctly separate obligation of National 
Treatment ex Article XVII, ${ }^{27}$ there would be no violation of the GATS and no need for a justification ex Article XIV.

It would seem evident that this very issue would not only be germane but indispensable in the resolution of the actual Gambling case. Even having found, the continuous and consistent protestations of the United States notwithstanding, that Gambling was covered by the Commitment, it would surely be necessary to consider whether the banning of one form of gambling services, namely Internet gambling, could in itself, according to the first view outlined above and as the Panel found, amount to a 'zero quota' on a covered commitment, or whether, in line with the second view, it was simply an origin-neutral internal regulation of the gambling sector pursuant to certain public-policy considerations, no different than, say, a prohibition of gambling on Sundays, or a prohibition of Gambling by Minors, which would still allow nondomestic providers to supply gambling services in the US and on the same conditions as domestic providers, just as, say, US providers provide gambling services in Macao but are subject to the various regulatory regimes of the local government.

And yet, as indicated above, this issue - both the question of principle, as well as its application to the factual circumstances of the case - remains unresolved even after the appeal.

This curious outcome is the result of what appears to be a serious error of 'lawyering' by the United States, who raised the point and then abandoned it, combined with a legally puzzling willingness of the Appellate Body to acquiesce in such an omission and to move to a decision, somehow papering over the need to resolve it, without, however, confirming the legal construct of the Panel on this point.

In its notice of Appeal, the US raised the issue by appearing to challenge:

The Panel's finding that a WTO Member does not respect its GATS market access obligations under Article XVI: (2) if it limits market access to any part of a scheduled sector or subsector, or if it restricts any means of delivery under mode 1 with respect to a committed sector. ${ }^{28}$

27 On the actual facts of the Gambling case, because the United States legal regime discriminated in favor of a variety of domestic providers, there probably was a violation of Article XVII. Since the Panel found and the Appellate Body affirmed a violation of Article XVI, it was not necessary to address directly Article XVII, and the issue of discrimination only became relevant in the context of Article XIV, where, indeed, it was fatal to the attempted justification of the measures found to have violated Article XVI. In relation to Horserace Gambling the 'Compliance Panel' found, inter alia, that '[s]ome of the suppliers and industry associations also confirm that they operate under the IHA. Most of these suppliers State that they accept wagers placed in other States. ${ }^{27}$ These suppliers are substantial and even prominent businesses with, collectively, thousands of employees and apparently tens of thousands of clients, paying taxes or generating revenue for government owners, having traded openly for up to 30 years and in some cases even operating television channels. Three are publicly listed corporations making filings with the United States Securities and Exchange Commission or subsidiaries of such corporations' (Recital 6.115; footnotes omitted).

28 Quoted from AB decision Recital 219, which refers to US Notice of Appeal, para. 3(c). 
The findings in question, from Recitals 6.287 and 6.290 of the Panel were that:

(i) as regards a particular service, a Member that has made an unlimited market access commitment under mode 1 commits itself not to maintain measures that prohibit the use of one, several or all means of delivery of that service; and (ii) a Member that has made a market access commitment in a sector or subsector has committed itself in respect of all services that fall within the relevant sector or subsector. ${ }^{29}$

At this point, it is worth quoting from the $\mathrm{AB}$ Report in extensu:

The United States did not, however, adduce any arguments in support of such a challenge in its appellant's submission. Nor did the United States expressly refer to, or request us to reverse, any paragraph of the Panel Report in which the 'finding' referred to in the above excerpt is found. Accordingly, we understand that the United States does not challenge separately the Panel's findings as regards restrictions on the supply of part of a sector, or as regards restrictions on part of a mode of supply (that is, on one or more means of supplying a given service). In response to questioning at the oral hearing, the United States confirmed that its appeal focuses on the Panel's interpretation of sub-paragraphs (a) and (c) of Article XVI: (2), and we shall limit our examination accordingly. ${ }^{30}$

It is inexplicable why the United States would have flagged in their notice of appeal this issue of doctrinal and conceptual principle and then abandon it in their argument. On this point in the Appeal, they seem to concentrate almost entirely on questions related to the form of the restriction - arguing essentially that their measures are not 'in the form of numerical quotas' or 'numerical units in the form of quotas' as required by the language of Article XVI: (2)(a) and (c) respectively, but seeming to cede that if it were to be found that their measure was 'numerical', then it would in fact constitute a violation of Article XVI. They do not, having initially raised the issue, argue that even if the measures could, if in fact they amount to a zero quota, be covered by Article XVI; this is not the case here since the sector of gambling remains open, and the measures, whilst certainly affecting certain possible modes of gambling, do not amount to a zero quota of the committed service in its totality.

Formally, if the US de facto abandoned this ground for appeal, the Appellate Body could so 'limit its examination'. The Appellate Body, so adept at 'completing the analysis' even when it applies to factual questions, which are typically outside its proper province, was happy to leave this gaping hole in this construction of Article XVI: (2). Its entire analysis, showing that measures having an effect to zero quotas are covered by Article XVI: (2)(a) and (c), is premised on the measures in question in fact constituting a zero quota. But this would depend on

29 The Quote is from the AB Report, footnote 262.

30 Recital 220, emphasis in the original but footnotes omitted. 
the manner in which one construes the issue just left open. And yet, while explicitly refusing to endorse the Panel's construction of this issue, it nevertheless proceeds as if it has. It is often a commendable feature of courts and tribunals - a sign of jurists' prudence - to avoid deciding moot points or issues not sufficiently argued before them. But in this case, since its eventual finding depends on this issue, the Appellate Body should, it is respectfully submitted, have 'completed the legal analysis', prodding both parties to brief it adequately on the issue. Further questioning is a device not open only to the Panels.

\section{The decision of the Appellate Body: textual fetishism and policy phobia}

In turning to examine the remaining issue of Market Access ex Article XVI: (2), we will henceforth assume that the measures in question did in fact have the effect of a 'zero quota' - even if this finding would depend on a legal premise that the Appellate Body left unanswered.

Article XVI: (2) provides:

2. In sectors where market-access commitments are undertaken, the measures which a Member shall not maintain or adopt either on the basis of a regional subdivision or on the basis of its entire territory, unless otherwise specified in its Schedule, are defined as:

(a) limitations on the number of service suppliers whether in the form of quotas, monopolies, exclusive service suppliers or the requirements of economic needs test;

...

(c) limitations on the total number of service operations or on the total quantity of service output expressed in terms of designated numerical units in the form of quotas or the requirement of an economic needs test.

The prohibitions contained in the US Acts do not seem to be in the form of numerical quotas or expressed in terms of designated numerical units in the form of quotas even if they do have the effect of a zero quota. This is not just a lexical or textual issue. After all, as we are reminded ad tedium in case after case, Article 31 of the VCLT provides:

A treaty shall be interpreted in good faith in accordance with the ordinary meaning to be given to the terms of the treaty in their context and in the light of its object and purpose.

As noted by the International Law Commission (ILC) - the original drafter of Article 31 of the Vienna Convention - in its commentary to that provision:

The Commission, by heading the article 'General Rule of Interpretation' in the singular and by underlining the connexion between paragraphs 1 and 2 and again between paragraph 3 and the two previous paragraphs, intended to indicate that 
the application of the means of interpretation in the article would be a single combined operation. All the various elements, as they were present in any given case, would be thrown into the crucible and their interaction would give the legally relevant interpretation. Thus [Article 31] is entitled 'General rule of interpretation' in the singular, not 'General rules' in the plural, because the Commission desired to emphasize that the process of interpretation is a unity and that the provisions of the article form a single, closely integrated rule. ${ }^{31}$

It has become obvious over the years, and Gambling is but the latest instance, that the Appellate Body has difficulties in treating the provisions of Article 31 of the Vienna Convention on Treaty Interpretation as a single, closely integrated rule. It privileges the textual and the contextual (the 'ordinary meaning' of terms ${ }^{32}$ ) and grudgingly and sparingly analyzes the teleological, as if engaging in serious object and purpose analysis (other than a perfunctory textual citation of phrases from this or that preamble) which is somehow itself a supplementary means of interpretation. A rather typical statement of the Appellate Body illustrates this 'hierarchical' approach to the elements of Article 31:

Article 31 of the Vienna Convention provides that the words of the treaty form the foundation for the interpretive process: 'interpretation must be based above all upon the text of the treaty ... [ $t$ ] he provisions of the treaty are to be given their ordinary meaning in their context. The object and purpose of the treaty are also to be taken into account in determining the meaning of its provisions'. ${ }^{33}$ (emphasis added)

At issue in the Gambling dispute is not simply a lexical conflict between the text of the United States measures and the text of Article XVI: (2)(a) and (c). There is also a deep-seated policy tension.

31 Yearbook of the ILC, 1966, Vol. II, pp. 219-220.

32 The Panel in Section 301 Case explained: 'Text, context and object-and-purpose correspond to well established textual, systemic and teleological methodologies of treaty interpretation, all of which typically come into play when interpreting complex provisions in multilateral treaties. For pragmatic reasons the normal usage ... is to start the interpretation from the ordinary meaning of the "raw" text of the relevant treaty provisions and then seek to construe it in its context and in the light of the treaty's object and purpose. However, the elements referred to in Article 31 - text, context and object-and-purpose as well as good faith - are to be viewed as one holistic rule of interpretation rather than a sequence of separate tests to be applied in a hierarchical order. Context and object-and-purpose may often appear simply to confirm an interpretation seemingly derived from the "raw" text. In reality it is always some context, even if unstated, that determines which meaning is to be taken as "ordinary" and frequently it is impossible to give meaning, even "ordinary meaning”, without looking also at object-and-purpose.' United States: Sections 301-310 of the Trade Act of 1974, Panel Decision WT/DS152/R at Recital 7.22.

33 Appellate Body report on Japan - Taxes on Alcoholic Beverages ('Japan - Alcoholic Beverages'), WT/DS8/AB/R, adopted 1 November 1996, pp. 11-12. Also notable is the understanding of the Appellate Body that the object and purpose in question are limited to those of the Treaty as a whole as if excluding the object and purpose of the provisions under interpretation. Although Article 31 refers to 'its' (the treaty's) object and purpose, this is so simply because it so agrees with the subject of the entire sentence. Other international tribunals and, notably the World Court have not limited object and purpose analysis only to that which can be culled from the Preamble of the instrument as a whole'. 
The lexical argumentation is fully ventilated. The United States, armed with that great legal authority, the New Shorter Oxford English Dictionary, explains that numerical actually pertains to numbers. The Panel, in looking at XVI: (2)(c) for example, resorts to the Spanish and French texts. The French version reads, 'limitations concernant le nombre total d'opérations de services ou la quantité totale de services produits, exprimées en unités numériques déterminées, sous forme de contingents ou de l'exigence d'un examen des besoins économiques'; and the Spanish version reads, 'limitaciones al número total de operaciones de servicios o a la cuantía total de la producción de servicios, expresadas en unidades numéricas designadas, en forma de contingentes o mediante la exigencia de una prueba de necesidades económicas'.

Since, in both these texts, there is a comma before the words 'in the form of quotas', the Panel concluded that numerical units and form of quotas were two separate ways in which a Member might violate its obligations, and that the US measures, while not expressed in numerical units, were in a form of a quota.

The Appellate Body, for its part, destabilizes both these arguments and reaches the conclusion that all three languages are grammatically ambiguous. After an exhaustive and sophisticated analysis, they come to the conclusion that the text in (c) does not preclude its application to a measure that produces a zero quota. They reach the same result in relation to the text in XVI: $(2)(a){ }^{34}$ This allows them to turn to supplementary means. In relation to (a) they turn to the 1993 Scheduling Guidelines and find an example pertaining to Article XVI: (2), namely: 'nationality requirements for suppliers of services (equivalent to zero quota)'. ${ }^{35}$ For the Appellate Body, this is dispositive: 'This example confirms the view that measures equivalent to a zero quota fall within the scope of Article XVI: 2(a). ${ }^{{ }^{36}}$ Also in relation to (c), they resort to the same Scheduling guidelines. In this case, the example they come up with is ' $[\mathrm{r}]$ estrictions on broadcasting time available for foreign films'. ${ }^{37}$ The Appellate Body then reasons:

The strict interpretation of Article XVI: 2(c) advanced by the United States would imply that only limitations that contain an express reference to numbered units could fall within the scope of that provision. Under such an interpretation, subparagraph (c) could not cover, for example, a limitation expressed as a percentage or described using words such as 'a majority.' It is neither necessary nor appropriate for us to draw, in the abstract, the line between quantitative and qualitative measures, and we do not do so here. Yet we are satisfied that a prohibition on the supply of services in respect of which a full market access commitment has been undertaken is a quantitative limitation on the supply of such services. $^{38}$

34 See Recitals 247 and 236 respectively.

35 Recital 237, citing p. 6 of the Scheduling Guidelines.

36 Recital 237.

37 Recital 249, citing the Guidelines on p. 6.

38 Recital 250. 
What is remarkable in this display of hermeneutics is the near total absence of any teleological analysis. The resort to context, or to supplementary means of interpretation, is simply so as to find another source of what the Appellate Body believes is clearer lexical support. Not only does it not seem even to follow its rather reductionist view of teleology cited above - 'The object and purpose of the treaty are also to be taken into account in determining the meaning of its provisions ${ }^{39}$ - it seems positively to avoid such analysis.

In relation to Article XVI: (2)(c), the Appellate Body, when resorting to supplementary means refers not only to the Scheduling Guidelines but to a Statement of a Co-Chairman of the negotiations. There follows the reasoning of the Appellate Body in full.

The market access obligations set forth in Article XVI were intended to be obligations in respect of quantitative, or 'quantitative-type', measures. The difficulties faced by the negotiating parties concerned not whether Article XVI covered quantitative measures - for it was clear that it did - but rather how to 'know where the line should be drawn between quantitative and qualitative measures' ${ }^{40}$

The meaning of the Co-Chair statements seems fairly obvious: The drafters of Article XVI: (2) had to grapple with and draft a text that, on the one hand, would prohibit quantitative measures that would contradict a Member's commitment, negotiated and freely given, to allow market access to nondomestic-services providers as expressed in its schedule, and, on the other hand, would still allow qualitative measures - which may indeed have a limiting impact on the provision of services but which, nonetheless, must be permitted as an expression of the regulatory freedom that all Members continue to enjoy.

Resolving that tension is one of the principal objectives of Article XVI: (2). All textual and contextual exegesis, as the Vienna Convention on the Law of Treaties instructs, has to be done in the light of such object and purpose. It is also clear why, since the words chosen by the drafters were so chosen in order to serve an object and purpose the drafters had in mind. Even, in the more limiting language of the Appellate Body this object and purpose, as articulated by the Co Chairman is 'also to be taken into account in determining the meaning of [the] provisions'.

And yet, as seen above, the Appellate Body not only avoids any discussion of the policy underlying the provision it is interpreting. It valorizes such avoidance: 'It is neither necessary nor appropriate for us to draw, in the abstract, the line between quantitative and qualitative measures, and we do not do so here. ${ }^{41}$ Then, with no more, they simply state that 'a prohibition on the supply of services in respect of

39 Appellate Body report on Japan-Taxes on Alcoholic Beverages (Japan-Alcoholic Beverages), WT/DS8/AB/R, adopted 1 November 1996, pp. 11-12.

40 Recital 248, citing 'Statement by the Co-Chairman at the meeting of 17-27 September 1991', MTN.GNS/45 Para. 16 (footnotes omitted).

41 Recital 250. 
which a full market access commitment has been undertaken is a quantitative limitation on the supply of such services'. ${ }^{2}$

The textual and contextual analysis of the Appellate Body is important and necessary, but they take it one step too far. It allows the Appellate Body, in the first place, to demonstrate the textual ambiguity of Article XVI: (2), which, in turn, permits them to turn to Supplementary Means ex Article 32 of the VCLT. The few textual snippets or examples found from the trawling of these 'Supplementary Means' are important in demonstrating that the interpretation adopted by the Panel and confirmed by the Appellate Body cannot be excluded. But to suggest that these snippets (which not even the parties to the dispute let alone the Panel considered fundamental) may, on their own, resolve the textual ambiguity, without any attempt to locate the problem and its solution in the light of object and purpose, is, ironically, not the hermeneutics indicated by the ordinary meaning of the terms of the Vienna Convention on the Law of Treaties and leaves this fundamental interpretation of Article XVI GATS on the flimsiest of lexical grounds.

We find a similar 'escape from policy' in the Appellate Body's analysis of XVI: (2)(a).

Here, too, the Appellate Body acknowledges that an important policy consideration undergirds the issue.

In Recital 223, they first cite the holding of the Panel:

In interpreting sub-paragraph (a) of Article XVI: 2, the Panel determined that:

[a prohibition on one, several or all means of delivery cross-border] is a 'limitation on the number of service suppliers in the form of numerical quotas' within the meaning of Article XVI: 2(a) because it totally prevents the use by service suppliers of one, several or all means of delivery that are included in mode 1.

In Recital 224, they then turn to the American appeal from this holding:

The United States submits that this interpretation ignores the text of subparagraph (a), in particular the meaning of 'form' and 'numerical quotas', and erroneously includes within the scope of Article XVI: 2(a) measures that have the effect of limiting the number of service suppliers or output to zero. Although the Panel opined that any other result would be 'absurd', the United States stresses the opposite - that a contrary result would be consistent with the balance between liberalization and the right to regulate that is reflected in the GATS.

We note that the American submission, even as very briefly summarized by the Appellate Body, reads the textual and contextual argument in the light of the general policy consideration - the need for that balance between liberalization and the right to regulate.

And yet, in the following 15 Recitals of its Decision - from Recital 224 until its conclusion where it upholds verbatim the Panel's holding, the Appellate Body

42 Ibid. 
focuses entirely and almost exclusively on the textual and contextual. The one perfunctory reference to object and purpose is limited to a reference to the Preamble of the GATS as a whole (rather than to an engagement with the underlying purpose of the provision under scrutiny) and even there, quite exquisitely, the Appellate Body's appeal to object and purpose is to explain why such do not readily assist in interpreting the provision. ${ }^{43}$ In sum, the policy behind the text of the provision is not used either to provide the light under which the textual analysis is to take place as instructed by the VCLT nor are object and purpose more than minimally taken into account as the Appellate Body itself indicates should be the case.

One can only speculate about the motivation of this peculiar brand of hermeneutics developed by the Appellate Body and demonstrated so clearly in this case that repeatedly plays lip service to the VCLT while ignoring its holistic and integrative approach to text, context, and purpose.

Our impression is that it is driven by an understandable and laudable concern by the Appellate Body for the legitimacy of its decisions and its very own position in the institutional matrix of the WTO. It appears to be based on the belief that a very strong textual grounding of its decision is the key for such legitimacy, since such grounding, more than any other, links judicial outcomes to the real intention of the Parties and makes them, and their Treaty, rather than the Appellate Body, their mere mouthpiece of the law, masters of, and responsible for, the content of WTO legal obligations.

In this way, it palpably draws a sharp distinction between, for example, the legal path the European Union has taken under the tutelage of the European Court of Justice (which has championed a strong teleological hermeneutics) and, appropriately, the very different legal path that it, the Appellate Body, is charting for the WTO - despite the fact that both judicial bodies often find themselves interpreting very similarly drafted material provisions.

Even on this issue, we agree with what appears to be the underlying ethos of the Appellate Body and distance ourselves expressly from that school of thought that would like to see a 'constitutionalization' of the WTO and so forth. ${ }^{44}$

And yet we doubt if, in the long run, this overreliance on textualism and 'textual-contextualism ${ }^{45}$ to the exclusion or near exclusion of object and purpose is, indeed, the path to legitimacy. Exaggerated textualism is as undermining as is exaggerated teleology since, among many other concerns, at a profound level it severs the legitimating nexus between the law as the handmaiden of its social, political, and economic goals. One measure of legitimate judicial decisionmaking is reflected in the attitude of losing parties. Over-textualized decisions deracinated

43 Recital 235.

44 See Weiler and Trachtman (1997).

45 By which we mean the use of the contextual method by the Appellate Body simply as a means to find additional sources, the wording of which supports their interpretation. This is much in evidence in this case, too. See, e.g., Recital 233. 
from the policy objectives of the law leave the loser with the impression of having 'lost on a technicality'. When, increasingly, as in this case and others, ${ }^{46}$ the textual and contextual arguments that turn out to be dispositive are such that neither party to the dispute, nor the Panel, nor even the WTO secretariat, ${ }^{47}$ considered fundamental, the Appellate Body's textual fetish and policy phobia has the paradoxical effect of rendering it not the mouthpiece of the law but quite the opposite, its oracle.

There is one additional cost the system is paying for this approach. Inevitably, lawyers take their hermeneutic cues from the judicial organ before which they appear and hope to win cases. The 'battle of the dictionaries', which so frequently characterizes arguments before the $\mathrm{AB}$, and the palpable tilting in the respective weight given to the various elements of Article 31 VCLT are evidence to a worrying and impoverishing shift of legal discourse in the universe of actual WTO dispute settlement.

It is important to emphasize that we are not making these points polemically or argumentatively. We are not engaged in a would-be appeal against this interpretation of Article XVI by the Appellate Body; indeed, we agree (with some reserves and limitation) with the substance of the legal interpretation. But we note the discrepancy between the remarkable conceptual and pragmatic significance of the decision-which paradoxically brings it closer to EC thinking-and its flimsy hermeneutic basis. Caught between its textual fetish and its policy phobia, the Appellate Body ends up undermining the very legitimacy it so assiduously courts.

\section{Balancing open markets and regulatory autonomy: some policy considerations}

It is possible to cull some of the essential policy considerations from within the decision of the Appellate Body itself. As already noted, the Co Chair of the Drafting Meeting considering Article XVI regarded the Article as attempting to draw some kind of line between 'quantitative and qualitative' measures - the first forbidden, the latter permitted. In the American submission, this translated into a 'balance between liberalization and the right to regulate', which are reflected in the GATS. Let us first try and tease out the tension that informs these two statements.

In paragraph 6.332 of its Report, the Panel reasoned that:

To hold that only restrictions explicitly couched in numerical terms fall within Article XVI: 2(a) would produce absurd results. It would, for example, allow a law that explicitly provides that 'all foreign services are prohibited' to escape the application of Article XVI, because it is not expressed in numerical terms.

46 Cf., e.g., the LAN decision.

47 The views of which weigh heavily in the Panel decisions. 
We agree, but it is partly the textual absurdity of the example that produces the absurd result and does not capture the American argument at its strongest. We do not think that even the US would regard a measure that explicitly said all foreign services are prohibited as not coming within the ambit of the prohibition on Market Access expressed in Article XVI.

To capture the dilemma, we should consider, in the first place, a measure that is origin neutral, applies equally to domestic and foreign services, and is not, on its face, about market access as such but has an impact on the provision of services.

Imagine, say, a commitment in the Advertising Sector enabling the providers of foreign advertising services to enter the domestic market. Imagine then that the State that took such a commitment passed an origin-neutral law that forbade Billboard advertising in the interest of preserving the natural beauty of the environment as is now common in many countries. Imagine an agency whose specialty is that particular mode of providing advertising. It (and its domestic counterpart) would be faced with a measure having an effect equivalent to a zero quota. With a moment's thought, one can see that there would be literally an innumerable number of regulatory provisions of the State enacted pursuant to various public policies that would have such an effect on service providers, domestic and foreign: prohibition on television advertising of tobacco or alcohol products; prohibitions dictated by considerations of public morality such as the use and abuse of sexuality in advertising, the duration of advertising spots in any single hour of broadcasting, etc. In fact, almost any regulatory regime can translate into some quantitative numerical impact on the provision of services, and in cases where the regulation is not as to the commercial arrangement of the provision of the service ${ }^{48}$ but go to the provision of service itself ${ }^{49}$ will amount to some form of 'zero quota' on a service provider whose business is limited to that which the regulation prohibits.

In part, this goes to the issue of limitations on market access in respect of part of a committed sector and limitations on one or more means of cross-border delivery for a committed service on which, as mentioned above, the Appellate Body expressly withheld judgment. But it does end up upholding the Panel finding in relation to Article XVI: (2)(a) that:

[a prohibition on one, several or all means of delivery cross-border] is a 'limitation on the number of service suppliers in the form of numerical quotas' within the meaning of Article XVI: 2(a) because it totally prevents the use by service suppliers of one, several or all means of delivery that are included in mode 1 .

48 Such as opening hours, labor-protection laws, etc. 49 E.g., no TV advertising of alcohol or tobacco. 
And that, in relation to Article XVI: (2)(c):

that a measure prohibiting the supply of certain services where specific commitments have been undertaken is a limitation:

... within the meaning of Article XVI: 2(c) because it totally prevents the services operations and/or service output through one or more or all means of delivery that are included in mode 1 . In other words, such a ban results in a 'zero quota' on one or more or all means of delivery include[d] in mode $1 .^{\mathbf{5 0}}$

Indeed, in its analysis, the Appellate Body seems to go even further than the Panel. The Panel is careful to insist that its ruling is limited to situations where the internal measure can be shown totally to prevent the provision of services. The Appellate Body uses language which seems to suggest that any internal prohibition which has a quantitative impact on the supply of services will be caught by Article XVI: $(2)(c)$ :

The strict interpretation of Article XVI: 2(c) advanced by the United States would imply that only limitations that contain an express reference to numbered units could fall within the scope of that provision. Under such an interpretation, subparagraph (c) could not cover, for example, a limitation expressed as a percentage or described using words such as 'a majority'. It is neither necessary nor appropriate for us to draw, in the abstract, the line between quantitative and qualitative measures, and we do not do so here. Yet we are satisfied that a prohibition on the supply of services in respect of which a full market access commitment has been undertaken is a quantitative limitation on the supply of such services. ${ }^{51}$ (emphasis added)

Be this as it may, under either construct this result seems to us no less absurd than the examples used by the Panel and the Appellate Body. Is it really conceivable that this is the balance between quantitative and qualitative the Members had in mind in drafting Article XVI: (2). Were the Members committing themselves that any origin-neutral internal regulation that takes the form of some prohibition of the manner in which services are offered and that as a result has a quantitative impact, or even any such measure that has a zero effect on any slice of the service in question, becomes a violation of their market-access commitment, and as such is challengeable and places on them the burden to justify under Article XIV? Would not, in this type of case, the appropriate locus for legal scrutiny be Article XVII on national treatment?

The US position is, in our view, equally untenable though not because of the potential of textual circumvention and abuse that, characteristically, the Panel and the Appellate Body employ. ${ }^{52}$ The opening up of the services sector

50 Recitals 239 and 252 respectively.

51 Recital 250.

52 The Appellate Body is troubled that, under the American approach, Article XVI: (2)(c) could not cover 'a limitation expressed as a percentage or described using words such as "a majority"'. Ibid. The Panel on Article XVI: (2)(a): The American approach 'would ... allow a law that explicitly provides that 
to foreign providers is not just, or always, or often, the result of noble self-interest. It is just as often, or more often, the result of tough negotiations and complex bargains struck. Now imagine a Member, such as the US, with a huge and lucrative gambling sector that decides, as part of such a complex bargain, to make an unrestricted commitment in its schedule in respect of foreign providers of gambling services. Imagine further that after some time a new administration is elected and for moral and other noncommercial reasons imposes a blanket prohibition on all gambling services, regardless of the national origin of the provider. It is not on its face an access measure, since the provision of that service internally is denied. It is really an internal regulation, part of the criminal law, but it has of course the effect of denying market access to all providers of gambling services.

The problem of the US position in Gambling is not linked to whether, in its verbal expression, such a prohibition uses numericals or otherwise as the Panel seems to think. The problem is that according to the American rationale, however drafted, since this is an internal regulatory measure, which simply has the effect of shutting out the supply of services by foreign providers, it should not in their view, as such, be caught by Article XVI: (2). This, too, seems to us a position that it would be difficult to square with the intended balance between the quantitative and qualitative in the drafting of Article XVI.

Though the Appellate Body says it is neither necessary nor appropriate to draw, in the abstract, a line between quantitative and qualitative measures and claims not to have done so. But, of course, it cannot avoid the legal and policy implications of its rulings simply by refusing to articulate the implicit assumptions and reasoning that undergird them. It may not have consciously drawn a line and thus leave those who must be guided by its decisions in the dark. But, in fact, its ruling and its reasoning, such as it is, may be understood or misunderstood as suggesting a line which tilts the balance away from the qualitative towards the quantitative, away from regulatory autonomy and towards WTO oversight over a rather wide array of internal, origin-neutral regulation in the services area.

If this becomes the common understanding of the import of this decision, right or wrong, one undesirable impact it might produce is a chilling effect on the willingness of Members to make commitments and/or to circumscribe such commitments as they do eventually make.

In what follows, we want to offer some consideration how one might think in a principled manner about the tension between the liberalization and regulatory autonomy in Article XVI: (2) and even, as is surely appropriate and necessary at

"all foreign services are prohibited". It is only in the textualist "Alice in Wonderland', which WTO dispute settlement sometimes resembles, that a Panel or the Appellate Body could believe that a Member would institute a total ban on foreign services and believe that it could get away with it, or even argue that it could get away with it, because it framed such a ban by a clever use of language that avoided numerals. However, if this hermeneutic trend continues, we might eventually find ourselves all turning into legal Mad Hatters. 
least for serious academic writing, attempt to draw a line between the quantitative and the qualitative. We are aware that we are placing our necks squarely on the chopping block. We are also aware that there will be no shortage of executioners. But our hope is that, by doing so, we will be starting a conversation that eventually will lead to a closing of the two major gaps left open by the decision of the Appellate Body in Gambling.

\section{Drawing the line - $a$ 'comparative' look at the GATT and the EU}

The question is whether an internal regulatory measure that quantitatively affects the marketplace applies not only to services but also to goods. And the policy tensions and balancing while not identical are not unsimilar. Let us follow in the footsteps of the Appellate Body and look, too, at any illumination that can be achieved from the GATT. ${ }^{53}$

The GATT has an analogous structure to Articles XVI and XVII. Article XI GATT plays in relation to goods the function that grosso modo Article XVI plays in relation to GATS. It is different in that it already makes the commitment to quantitatively unimpeded access that under the GATS is voluntary. But it is similar in that it attempts, additionally, to describe the conditions under which such access would be compromised.

Article III of the GATT is the counterpart of Article XVII of the GATS. It constitutes the discipline that governs the tax and regulatory regime applied within a State's marketplace. There is a duty not to treat the imported goods in a manner so as to afford protection to domestic production and an analogous duty in respect of 'imported' (foreign) services and service providers.

There is, however, a similar category of measures in relation to which it is not clear whether they are meant to be covered by Article XI or Article III. Imagine a State measure, addressed in equal manner to domestic and imported producers and products, which said that one may not market in the State an automobile that did not have side airbags. The effect of this measure would, of course, exclude from the marketplace any imported vehicle that did not have side airbags. As such, it could be argued that it violates Article XI - the market-access Article in the GATT and hence be illegal. Alternatively, it could be argued that this is not a market-access measure at all, but an origin-neutral internal regulatory measure that applies equally to domestic and imported products and, as such, is covered only by the discipline of Article III.

In the GATT, the issue to date has been resolved by the Agreement itself. Ad note III provides that origin-neutral regulatory measures, not specifically directed at imports, are covered by Article III (national treatment) and not by Article XI (Quantitative Restrictions). 


\section{Ad Article III}

Any internal tax or other internal charge, or any law, regulation or requirement of the kind referred to in paragraph 1 which applies to an imported product and to the like domestic product and is collected or enforced in the case of the imported product at the time or point of importation, is nevertheless to be regarded as an internal tax or other internal charge, or a law, regulation or requirement of the kind referred to in paragraph 1 , and is accordingly subject to the provisions of Article III.

We can only speculate about the policy behind this. It could be argued that to hold otherwise would become a wholesale assault on the regulatory autonomy and sovereignty of a Member if each and every internal regulation that was origin neutral and simply defined regulation of the internal marketplace, and that happened to affect imports as well, would be considered as a violation of Article XI, which prohibited quantitative restrictions and would require the State to justify itself before the WTO. As argued above, almost every safety regulation, every labeling requirement, every health measure relating to products would, of course, affect imported products and become per se a violation of the market-access provision Article XI - even if it was applied in equal measure to domestic products.

It could, however, be motivated by quite the opposite policy consideration. In the early days of the GATT, most extant quantitative restrictions were grandfathered and Article XI was read as de facto applicable only to new Quantitative Restrictions. If one were to take the view that internal regulations that had an equivalent effect to border quantitative restrictions were to be considered as covered by Article XI and then apply to all of those the Grandfathering provisions applied to extant Quotas, the GATT would have been gutted. Ad note III thus ensured that all these measures that, in fact, did have an effect equivalent to a quantitative restriction would, at least, be scrutinized under Article III.

The US position in the Gambling dispute would have the GATS adopt a position analogous to the GATT and hold that internal measures, even those that totally exclude a service and amount to measures having an effect equivalent to a zero quota, should not be considered under Article XVI just as in the GATT they are not considered under Article XI. Why, it could be argued, would the Members even contemplate changing the settled logic of the GATT in its extension to services through the GATS ? It would seem on this view odd if the GATS, unlike the GATT, were to be interpreted so that any origin-neutral internal measure that applies on its face equally to domestic services and foreign services and that had the effect of quantitatively limiting such services (both domestic and foreign) were to be construed as a violation of Article XVI, thereby opening the State to a suit by another Member and requiring justification by reference to the General Exceptions of the GATS before the WTO Dispute Settlement organs, all this in contrast with settled practice in the area of goods under the GATT.

There are however textual, contextual, and policy considerations that may counter that argument. First, is the inconvenience that this question in the GATT 
was settled by the Members in the Agreement itself by the inclusion of the explicit Ad Note III. Reasoning a contrario one could argue that the failure to include an analogous provision in the GATS cannot be attributed to forgetfulness and represents a deliberate choice that Ad Note III should not apply to GATS.

There could seem to be at least two policy considerations that may have informed such a choice. First, unlike Article XI GATT, which not only defines the circumstances under which access is to be deemed to have been denied, but also contains the material commitment that outlaws all quotas, Article XVI is only structural. A Member is not obliged to make any commitments in relation to services. Further, when it makes such commitments it can restrict them in any way it wishes (e.g., gambling, with the exception of Internet gambling). Thus, the Members have great autonomy to decide the extent of their market access in the way they draft their commitments. But once given, they should be held strictly to their bargains.

Second, in relation to goods, unlike services, the WTO took two giant steps in the form of the SPS and TBT Agreements towards a regime that does, in fact and law, allow one Member to sue another in respect of measures that are origin neutral and nondiscriminatory. Thus, to allow a challenge under Article XVI: (2) to restrictions on services that are origin neutral and nondiscriminatory would not seem to depart so much from the GATT, Ad Note III notwithstanding, in which so many cases of goods will come under the new SPS and TBT regime. In other words, since in the GATT, under SPS and TBT the Members already accepted that in vast areas nondiscriminatory measures could be challenged as inimical to trade liberalization, it did not seem such a radical decision not to include the equivalent of Ad Note III in the GATS.

It would, thus, seem that one cannot simply borrow the practice of GATT regime in relation to nonborder origin-neutral internal measures that have an effect equivalent to quantitative restrictions and apply it to Article XVI: (2) GATS. The arguments go in either way. One cannot avoid a choice based on some normative policy choice.

In this respect, the practice of the EC, at all times to be treated with caution given the very different telos of that Organization and the equally different economy of its founding Treaties, may be instructive in considering such a normative policy choice.

Famously in its Dassonville canonical statement, in the field of free movement of goods, the European Court ruled back in 1974, in the early days of the Common Marketplace that:

All trading rules enacted by Member States which are capable of hindering, directly or indirectly, actually or potentially, intra-Community trade are to be considered as measures having an effect equivalent to quantitative restrictions. ${ }^{54}$ 
The result of this ruling as eventually interpreted and applied in the EC was to make any internal rule, even origin-neutral rules not directed as such at trade, which had any quantitative impact on imports by placing on them any burden, a prima facie violation of the EC market-access provisions of the Treaties and requiring justification under the respective general-exceptions doctrine. This would be the impact if we were to give a similar meaning to the statement of the Appellate Body in Recital 250 of Gambling. ${ }^{55}$

About 20 years later, in the equally famous Keck decision, the European Court revisited this doctrine and clawed it back considerably:

contrary to what has previously been decided, the application to products from other Member States of national provisions restricting or probibiting certain selling arrangements is not such as to hinder directly or indirectly, actually or potentially, trade between Member States within the meaning of the Dassonville judgment (case 8/74 [1974] ECR 837), so long as those provisions apply to all relevant traders operating within the national territory and so long as they affect in the same manner, in law and in fact, the marketing of domestic products and of those from other Member States. ${ }^{56}$

The Court itself, uncharacteristically, addresses in Recital 14 of its decision the rationale:

In view of the increasing tendency of traders to invoke Article 30 of the Treaty as a means of challenging any rules whose effect is to limit their commercial freedom even where such rules are not aimed at products from other Member States, the Court considers it necessary to re-examine and clarify its case-law on this matter. ${ }^{57}$

Oceans of ink powder and forests of trees have been respectively consumed and decimated in trying to articulate the precise conditions under which Keck applies. We would argue for the understanding contained in the decision itself and fairly consistently applied in subsequent case law, namely that a State measure that has

55 The strict interpretation of Article XVI: 2(c) advanced by the United States would imply that only limitations that contain an express reference to numbered units could fall within the scope of that provision. Under such an interpretation, sub-paragraph (c) could not cover, for example, a limitation expressed as a percentage or described using words such as 'a majority'. It is neither necessary nor appropriate for us to draw, in the abstract, the line between quantitative and qualitative measures, and we do not do so here. Yet we are satisfied that a prohibition on the supply of services in respect of which a full market access commitment has been undertaken is a quantitative limitation on the supply of such services.

56 Joined Cases C-267/91 and C-268/91, Criminal Proceedings against Bernard Keck and Daniel Mithouard, [1993] ECR-I, 6097, Recital 16. The court thus concludes in Recital 17: 'Provided that those conditions are fulfilled, the application of such rules to the sale of products from another Member State meeting the requirements laid down by that State is not by nature such as to prevent their access to the market or to impede access any more than it impedes the access of domestic products. Such rules therefore fall outside the scope of Article 30 of the Treaty.'

57 Joined Cases C-267/91 and C-268/91, Criminal Proceedings against Bernard Keck and Daniel Mithouard, [1993] ECR-I, 6097, Recital 14. 
a quantitative effect will be caught by the Market Access provision only when the effect in question is such as totally to exclude the product from the marketplace. In addition, State measures will be scrutinized if they are discriminatory and protectionist.

Provided that those conditions are fulfilled, the application of such rules to the sale of products from another Member State meeting the requirements laid down by that State is not by nature such as to prevent their access to the market or to impede access any more than it impedes the access of domestic products. Such rules therefore fall outside the scope of Article 30 of the Treaty. ${ }^{58}$ (Emphasis added)

We believe this balance is promising also in the context of the WTO, both GATT and GATS.

On the one hand, once you allow products or services of another Member access to your market, such goods and services are to be welcome and treated no less favorably than domestic competitors (ex Article III GATT; Article XVII GATS). For their part, such goods or services should accept to be bound on an equal footing as their domestic competitors by the variety of sociopolitical, economic, and cultural choices of their host country, as reflected in its legal and regulatory regime. If the law and practice is to mandate - for example, that for social reasons, employees may not be made to work more than 38 hours a week or that there are mandatory opening and closing hours of businesses - a foreign importer of goods cannot complain that such amounts to a restriction on the access granted him, even though such regulation limits the amount of goods he may sell, any more than he could complain about the rate of income tax, or the law of contract that might have similar effects on the volume of his sales. Likewise in the area of services, if a provider of cinematographic entertainment, or television transmission, is told that he may not allow children into certain types of movies or that certain types of transmissions may only take place at certain late hours of the night, he may not complain, absent discrimination, that this amounts to a restriction on his ability to provide services. This is the market they have gained access to. The Member has promised access, but has not promised that Membership of the WTO will force it to change the social and cultural norms that are also reflected in its marketplace or even submit such to WTO approval. As the Appellate Body has explained more than once, even in the area of SPS and TBT, which put in place a discipline that may be violated without a show of discrimination or protectionism, a State is not required to lower its standards of risk or other sociocultural norms. ${ }^{59}$

On the other hand, under the same logic, when the effect of the internal regulation, even if not discriminatory, is actually to exclude totally a product or service

58 Recital 17 Keck.

59 See, e.g., Japan - Measures Affecting Agricultural Products, adopted by Dispute Settlement Body, 19 March 1999, WT/DS76/R and WT/DS/AB/R. 
lawfully traded in the market of your partner, then the Access provisions such as Article XVI GATS should be triggered. ${ }^{60}$ Note that we are speaking not of any negative quantitative effect that an internal measure might have, but an actual and full denial of access.

In support of this construction, we would want to offer the following considerations. First, an internal measure that totally excludes a good (or a service) that indeed has the effect equivalent to a zero quota, seems to be consistent with the purpose of such articles more than an internal measure that does not bar access but simply sets regulatory conditions for such even if they have some quantitative impact (you sell less).

Second, it should be remembered that bringing such measures under the canopy of Article XVI does not mean that the State has to abandon them but simply to justify them. One way of thinking of such is, as indicated above, as submission to WTO approval. A different and perhaps more convincing and appealing way is to think of this construct as being part of a 'Duty of Comity' towards one's trading partners. After all, if a product or a service is perfectly legal and acceptable in its place of origin, it may seem arbitrary to exclude such from the marketplace in the importing state. It may also seem offensive sending a signal that the 'exporting' country might care less about the welfare of its own market. An explanation as a matter of legalized comity would not be alien to the legal world of international trade. ${ }^{61}$

Thirdly, one of the benefits of an open-trading system is not only the efficiency gains but also the richness consumers in the importer market are exposed to through the introduction of new or different products and services. If a product or service is allowed, but simply subject to the regulatory requirements of the local market it is one thing. If they are actually excluded, it could be in the interest of domestic consumers to allow a challenge to such exclusions that, after all, might be motivated by Special Interests rather than the collective good. The Gambling dispute itself may illustrate this point. The 'Compliance Panel' found, inter alia, the existence in the USA of:

substantial and even prominent businesses with, collectively, thousands of employees and apparently tens of thousands of clients, paying taxes or generating revenue for government owners, having traded openly for up to 30 years and in some cases even operating television channels... The evidence regarding

60 In principle, under this theory also, Article XI GATT should be triggered, but that is expressly prohibited by the specially inserted Ad Note III.

61 See, for example, Article 2.5 of the TBT Agreement: 2.5: 'A Member preparing, adopting or applying a technical regulation which may have a significant effect on trade of other Members shall, upon the request of another Member, explain the justification for that technical regulation in terms of the provisions of paragraphs 2 to 4 . Whenever a technical regulation is prepared, adopted or applied for one of the legitimate objectives explicitly mentioned in paragraph 2, and is in accordance with relevant international standards, it shall be rebuttably presumed not to create an unnecessary obstacle to international trade.' 
these suppliers demonstrates the existence of a flourishing remote account wagering industry on horse racing in the United States operating in ostensible legality. ${ }^{62}$

Finally, such a distinction finds some textual support, too. The nature of numericals is their quantifiable precision. A domestic regulation that has an impact on the quantity of the goods sold or services offered, as would be the case with most internal regulatory regimes, would not be caught by the balance we are suggesting here on this ground, too: it has a quantitative effect but is not in the nature of a quota with its numerical precision. By contrast, the zero quota is of such a nature and thus to be caught. ${ }^{63}$

The application of this to the market in goods is easier than to the market in services. ${ }^{64}$ If the good in question is allowed on to the marketplace, even if under a variety of conditions, it should neither be caught nor justified, provided it is not subjected to a protectionist regime. As we have seen, it is much more difficult to have such a clean determination in the market of services. In the example used above, is the exclusion of billboard advertising a zero-quota on billboardadvertising providers or is it an internal regulation of the broader advertising industry?

A starting point in considering this issue, from which we would not wish at this point to go further, would be to suggest that if the internal regulation has the effect of totally gutting a service commitment, it would be an easy case in which Article XVI would be triggered. But it could not be the only case: in Gambling, the commitment was for entertainment under which so many disparate services may be included, that a total gutting principle would be too restrictive. On the other hand, the Panel's construct, which includes one, several, or all means of delivery, etc., might be too broad. The American measure was a zero quota only if one construed Internet gambling as a stand-alone service, rather than as means, such as billboard advertising, of providing gambling services. Would a ban, within Internet gambling, on say, the guessing game of Kino because of its long odds, be a regulation of Internet gambling or a zero quota on Kino?

The provisions for impairment and nullification always beckon as an 'easy' solution for difficult cases, but to resort to that difficult device as the systemic answer to this systemic question is not an alluring prospect.

Without resolving this issue, one cannot reach a safe conclusion on the Application of Article XVI: (2). This is of little comfort to the United States in this case, since they would, in any event, be caught under Article XVII for violation of the National Treatment provisions.

62 Compliance Panel 6.115 and 6.116.

63 (And we would also include, though very exceptional in reality, other quantitatively precise regulations, such as 'the Majority' example offered by the Appellate Body: Majority is of such a precise nature: more than $50 \%$.)

64 Cf. Pauwelyn (2006). 


\section{Article XIV-due process}

This case is notable by the aggressiveness of the Parties in accusing the Panel, albeit not in so many words, of judicial impropriety. ${ }^{65}$ For the most part, the $\mathrm{AB}$ has deflected such criticism. But, in this instance, it would be interesting to adopt a dynamic approach to the decision where the focus of our enquiry is not simply the propriety - legal or otherwise - of the decision but the impact it might have on the litigation strategies of parties in the future.

Antigua claimed that the US raised its defense ex Article XIV only in its second written submissions and that this fact compromised its ability to mount an effective response and, worse still, because of this tardiness and the consequent deficiency in the adversarial process, the Panel's 'ability to assess that defence' was hampered and, more gravely, that this resulted in 'the Panel's making the defence for the United States' (Recital 275).

The $\mathrm{AB}$ rejected the due-process charge of Antigua by stating that (a) Antigua 'was apparently aware that the United States might argue that its measures satisfy the requirements of Article XIV' (Recital 276); (b) that it raised no objection at the time of the proceedings (ibid.); and that (c) it did have an opportunity to respond adequately to the US submission, albeit at a late stage (ibid.).

This might not be taking due process all that seriously. In its First Written Submission, there is an indication that Antigua may have anticipated the use of Article XIV by the US - which in fact did not turn out to be the case either in the first US written or oral submissions. Antigua thus dropped the issue in its second written submissions only to discover that the US had raised them in its own second written submission. So, as the $\mathrm{AB}$ points out: 'Both parties discussed issues relating to Article XIV in their opening statements at the second substantive panel meeting' (Recital 274). In some respects, Article XIV was germane to the outcome of the case. This is rather unsatisfactory both in terms of due process and in terms of the benefit that the adversarial process is meant to yield. It is particularly poignant since part of the Article XIV holding turned on Antigua's failure to discharge its Least Restrictive Measures burden. Maybe this was a situation where the Panel should have exercised its powers under Article 12.2 of the DSU to allow for additional time to respond and perhaps even for additional submissions.

But beyond this point, one may wonder if, as a result of this part of the Ruling, perverse litigational strategies might develop. For example, Antigua was 'penalized' because in its first submission it briefly hypothesized about the possibility of an Article XIV defense. Should Members be discouraged from doing so? Should Members be encouraged to save some very material defenses

65 'The United States contends that the Panel's interpretation of Article ... XVI: 2(c) would "unreasonably and absurdly" deprive Members of much of their right to regulate services' Recital 26 of AB Report. See, too, Recital 12 “"egregious” nature of the Panel's approach.' 
to the Second Submission phases as a means of limiting the ability of their adversary to respond effectively? And should one encourage strategies of 'appeal protest' of parties before Panels so as not to be estopped later before the $\mathrm{AB}$ ?

\section{Article XIV 'relative importance' and the doctrine of 'vital interests'}

Gambling leaves one crucial issue for both GATT and GATS, tantalizingly ambiguous in relation to the usage of Articles XX GATT and Article XIV GATS. Korea-Beef features prominently in the decision as the yardstick for exception analysis. Interestingly, although the $\mathrm{AB}$ talks about the factors that are to be 'weighed and balanced' and the 'relative importance', it omits from its analysis explicit reference to the most controversial aspect of Korea-Beef. In that decision, it was clear that the necessity of a measure of enforcement, for example, was dependent on the 'vitality' of the interest protected. A question of life and death would justify a more exigent measure. Mere fairness of commercial transactions and consumer information would not justify such exigent measures. In effect, the Appellate Body was lucidly and overtly (perhaps inadvertently) spelling out what was noticeable in other contexts, namely that Members did not have full freedom to set their own acceptable level of risk in relation to the policy claimed under Articles XX GATT and XIV GATS. Enforcement, after all, impacts the level of risk that will be tolerable. If the separation of imported beef and domestic beef were to touch on life and death, the $\mathrm{AB}$ would have accepted a much more stringent enforcement mechanism. But since it affected less 'vital' interests, Korea was to satisfy itself with a regime that would allow a greater degree of violation of its policy.

In Recital 308 of Gambling, the AB ironically cites Korea-Beef for the more orthodox position, namely that a Member has a 'right to achieve its desired level of protection with respect to the objective[s] pursued under [Articles XX and XIV]'. How is this to be read? A retreat from the doctrine of Vital Interests or a mere retreat from the lucidity of Korea-Beef to the camouflage and fiction of Member autonomy in setting in all circumstances its own standards?

\section{6. (Insert heading as for 1-5)}

Finally, in our view, the $\mathrm{AB}$ has been wise in clarifying, once and for all, that the so-called duty of consultation is not an automatic requirement of Article XIV and XX as some have been wont to suggest in the wake of Turtle-Shrimp and Gasoline and that the burden of advancing actual LRMs rests on the defending party. $^{66}$

66 See Akbar, 'The 'Necessary' Connection Between the Duty to Negotiate and Least Restrictive Measures Analysis: The Gambling Dispute Reconsidered', Jean Monnet Working Papers 03/2007. 


\section{References}

Clarke, Roger and Gillian Dempsey (2001), 'The Feasibility of Regulating Gambling on the Internet', Managerial and Decision Economics, 22 : 125-132.

Grinols, Earl L. and David B. Mustard (2006), 'Casinos, Crime, and Community Costs', The Review of Economics and Statistics, 88: 28-45.

Hahn, Robert W. and Paul C. Tetlock (2006), 'A New Approach for Regulating Information Markets', Journal of Regulatory Economics, 29: 265-281.

Mavroidis, Petros (2007), 'Highway XVI Re-Visited: The Road from Non-Discrimination to Market Access in GATS', World Trade Review, 6(1): 1-23.

Kearney, Melissa S. (2005), 'The Economic Winners and Losers of Legalized Gambling', National Tax Journal, 58: 281-302.

Robert F. Nagel (1985), ‘The Formulaic Constitution', Michigan Law Review, 84: 165-212.

Ortino, Federico (2006), 'Treaty Interpretation and the WTO Appellate Body Report in US-Gambling: A Critique', Journal of International Economic Law, 9: 117-148.

Pauwelyn, Joost (2006), 'Rien ne Va Plus? Distinguishing Domestic Regulation from Market Access in GATT and GATS', World Trade Review, 4: 131-170.

Porges, Amelia (1989), 'Japan-Trade in Semi-Conductors, No. L/6309, The American Journal of International Law, 83(2): 388-394.

Voon, Tania (2006), 'To Uphold, Modify or Reverse? How the WTO Appellate Body Treats Panel Reports', The Journal of World Investment and Trade, 7: 507.

Weiler, J. H. H. and Joel P. Trachtman (1997), 'European Constitutionalism and Its Discontents', Northwestern Journal of International Law and Business, 354.

Wilson, Mark (2003), 'Chips, Bits, and the Law: An Economic Geography of Internet Gambling', Environment and Planning A, 35 : 1245-1260.

Wunsch-Vincent, Sacha (2006), 'The Internet, Cross-Border Trade in Services, and the GATS: Lessons from US-Gambling', World Trade Review, 5: 319-355. 


\section{Annex 1 - DSB summary of the case}

On 21 March 2003, Antigua and Barbuda requested consultations with the US regarding measures applied by central, regional and local authorities in the US which affect the cross-border supply of gambling and betting services. Antigua and Barbuda considered that the cumulative impact of the US measures is to prevent the supply of gambling and betting services from another WTO Member to the United States on a cross-border basis.

According to Antigua and Barbuda, the measures at issue may be inconsistent with the US obligations under the GATS, and in particular Articles II, VI, VIII, XI, XVI and XVII thereof, and the US Schedule of Specific Commitments annexed to the GATS.

On 12 June 2003, Antigua and Barbuda requested the establishment of a panel. At its meeting on 24 June 2003, the DSB deferred the establishment of a panel. Further to a second request by Antigua and Barbuda, the DSB established a panel at its meeting on 21 July 2003. Canada, the EC, Mexico and Chinese Taipei reserved their third-party rights. On 23 July 2003, Japan reserved its thirdparty rights.

On 15 August 2003, Antigua and Barbuda requested the Director-General to compose the panel. On 25 August 2003, the Director-General composed the panel. On 29 January 2004, the Chairman of the Panel informed the DSB that it would not be possible for the Panel to complete its work in six months because various factors had had an impact on the Panel's timetable, such as a party's request for preliminary rulings, the intervention of the holiday season, the heavy agenda of the panelists as well as the complexity of the legal and factual questions which had been raised. The Panel hoped to complete its work by the end of April 2004.

In the context of the negotiations for a mutually agreed solution to the present dispute, the parties requested the Panel to suspend the panel proceedings, in accordance with Article 12.12 of the DSU, until 23 August 2004. On 25 June 2004, the Panel has agreed to this request. The parties subsequently requested a continuation of the suspension until 4 October 2004, and the Panel agreed to the request on 18 August 2004. The parties requested a continuation of the suspension until 16 November 2004, and the Panel agreed to the request on 8 October 2004. On 5 November 2004 Antigua, requested the resumption of the panel proceedings to the Panel and the United States did not object to this request. The Panel has therefore agreed to resume the panel proceedings as from 8 November 2004.

On 10 November 2004, the report of the Panel was circulated to Members. The Panel found that:

- The GATS Schedule of the United States has been interpreted to include specific commitments for gambling and betting services under the sub-sector entitled 'Other Recreational Services (except sporting)';

- Three US Federal laws (the Wire Act, the Travel Act and the Illegal Gambling Business Act) and the provisions of four US State laws (those of Louisiana, 
Massachusetts, South Dakota and Utah) on their face, prohibit one, several or all means of delivery included in mode 1 of GATS (i.e. cross-border supply), contrary to the United States' specific market access commitments for gambling and betting services for mode 1 . Therefore, the United States failed to accord services and service suppliers of Antigua treatment no less favourable than that provided for under the terms, limitations and conditions agreed and specified in the US Schedule, contrary to Article XVI: 1 and Article XVI: 2 of the GATS (i.e. concerning market access);

- Antigua failed to demonstrate that the measures at issue are inconsistent with Articles VI: 1 and VI: 3 of the GATS (i.e. concerning domestic regulation);

- The United States was not able to invoke successfully the GATS exceptions provisions. In this regard, the United States was not able to demonstrate that the Wire Act, the Travel Act and the Illegal Gambling Business Act are 'necessary' under Articles XIV(a) and XIV(c) of the GATS (i.e. 'exceptions' provisions, including for public morals) and are consistent with the requirements of the chapeau of Article XIV of the GATS;

- The Panel decided to exercise judicial economy with respect to Antigua's claims under Articles XI (i.e. concerning payments and transfers) and XVII (i.e. concerning national treatment) of the GATS.

On 7 January 2005, United States notified its intention to appeal certain issues of law and legal interpretations developed by the Panel. On 19 January 2005, Antigua and Barbuda notified its intention to appeal certain issues of law and legal interpretations developed by the Panel.

On 8 March 2005, the Chairman of the Appellate Body informed the DSB that the Appellate Body would not be able to circulate its Report within the 60-day period due to the time required for completion and translation of the Report, and that it estimated it would be circulated to WTO Members no later than 7 April 2005.

On 7 April 2005, the report of the Appellate Body was circulated. The Appellate Body:

- upheld the Panel's finding that an alleged 'total prohibition' on the cross-border supply of gambling and betting services cannot, in and of itself, constitute a 'measure' subject to dispute settlement under the GATS;

- found that the Panel should not have ruled on claims advanced by Antigua with respect to eight State laws of the United States, as to which Antigua had not made a prima facie case of inconsistency with the GATS;

- upheld the Panel's finding, albeit for different reasons, that the United States' Schedule includes a commitment to grant full market access in gambling and betting services. In particular, in the course of its interpretation of the United States' Schedule, the Appellate Body disagreed with the Panel's designation of two documents - referred to as W/120 and the 1993 Scheduling Guidelines - as 'context' for the interpretation of Members' Schedules, finding instead that they constitute 'preparatory work'; 
- upheld the Panel's finding that the United States acts inconsistently with Article XVI: 1 and sub-paragraphs (a) and (c) of Article XVI: 2 by maintaining certain limitations on market access not specified in its Schedule; and

- reversed the Panel's finding that the United States had not shown that the three Federal statutes are 'necessary to protect public morals or to maintain public order', within the meaning of Article XIV(a); found that the United States' measures are justified under Article XIV(a) of the GATS as measures 'necessary to protect public morals or to maintain public order'; and upheld, albeit on a narrower ground, the Panel's finding that the United States had failed to show that these measures satisfy the conditions of the chapeau of Article XIV.

At its meeting of 20 April 2005, the DSB adopted the Appellate Body report and the Panel report, as modified by the Appellate Body report.

Implementation Status of Adopted Reports

At the DSB meeting of 19 May 2005, the United States stated its intention to implement the DSB's recommendations and indicated that it would need a reasonable period of time to do so. As the Antigua and Barbuda and the United States had failed to agree on a reasonable time period for implementation in accordance with Article 21.3(b) of the DSU, on 6 June 2005, Antigua and Barbuda requested that the reasonable period of time be determined through binding arbitration pursuant to Article 21.3(c) of the DSU. On 30 June 2005, pursuant to the request from Antigua and Barbuda, the Director-General appointed Dr. Claus-Dieter Ehlermann to act as arbitrator under Article 21.3(c) of the DSU. On 19 August 2005, the Arbitrator circulated his Award to the Members, determining that the reasonable period of time for implementation was 11 months and 2 weeks from 20 April 2005, expiring on 3 April 2006.

On 24 May 2006, the parties informed the DSB that, given the disagreement as to the existence or consistency of measures taken by the United States to comply with the recommendations and rulings of the DSB, they had agreed on certain procedures under Articles 21 and 22 of the DSU.

On 8 June 2006, Antigua and Barbuda requested consultations under Article 21.5 of the DSU. On 6 July 2006, Antigua and Barbuda requested the establishment of an Article 21.5 panel. At its meeting on 19 July 2006, the DSB referred the matter to the original panel, if possible. On 16 August 2006, the Panel was composed.

For details of the Article 21.5 panel, see above.

On 21 June 2007, Antigua and Barbuda requested authorization from the DSB, pursuant to Article 22.2 of the DSU, to suspend the application to the United States of concessions and related obligations of Antigua and Barbuda under the GATS and the TRIPS Agreement. On 23 July 2007, the United States (i) objected to the level of suspension of concessions and obligations proposed by Antigua and Barbuda and (ii) claimed that Antigua and Barbuda's proposal does not follow the principles and procedures set forth in Article 22.3 of the DSU. At its meeting on 24 July 2007, the DSB agreed that the matter referred to by the United States be referred to arbitration. 


\section{Annex 2: Summary of Main Legal Issues, as prepared by the Secretariat of the WTO}

http://www.wto.org/english/tratop_e/dispu_e/cases_e/1pagesum_e/ds285sum_e.pdf US - GAMBLING ${ }^{1}$ (DS285)

\section{MEASURE AND SERVICES AT ISSUE}

- Measure at issue: Various US measures relating to gambling and betting services, including Federal laws such as the 'Wire Act', the 'Travel Act' and the 'Illegal Gambling Business Act' ('IGBA').

- Services at issue: Cross-border supply of gambling and betting services.

\section{SUMMARY OF KEY PANEL/AB FINDINGS ${ }^{2}$}

- Scope of GATS commitments: The Appellate Body upheld, based on modified reasoning, the Panel's finding that the US GATS Schedule included specific commitments on gambling and betting services. Resorting to 'document W/120' and the '1993 Scheduling Guidelines' ${ }^{3}$ as 'supplementary means of interpretation' under Art. 32 of the VCLT, rather than context (Art. 31), the Appellate Body concluded that the entry, 'other recreational services (except sporting)', in the US Schedule must be interpreted as including 'gambling and betting services' within its scope.

- GATS Art. XVI: 1 and 2 (market access commitment): The Appellate Body upheld the Panel's finding that the United States acted inconsistently with Art. XVI: 1 and 2, as the US Federal laws at issue, by prohibiting the crossborder supply of gambling and betting services where specific commitments had been undertaken, amounted to a 'zero quota' that fell within the scope of, and was prohibited by, Art. XVI: 2(a) and (c). However, it reversed a similar finding by the Panel on State laws because it considered that Antigua and Barbuda ('Antigua') had failed to make a prima facie case with respect to these State laws.

- GATS Art. XIV(a) (public morals defence): The Appellate Body upheld the Panel's finding that the US measures were designed 'to protect public morals or to maintain public order' within the meaning of Article XIV(a), but reversed the Panel's finding that the United States had not shown that its measures were 'necessary' to do so because the Panel had erred in considering consultations with Antigua to constitute a 'reasonably available'

1 United States - Measures Affecting the Cross-Border Supply of Gambling and Betting Services.

2 Other issues addressed: confidentiality of panel proceedings; terms of reference; the relevance of statements by a party to the DSB; measure at issue (total prohibition); practice as a measure; establishment of a prima facie case; late submission of a defence (DSU Art. 11); burden of proof.

3 'W/120', entitled 'Services Sectoral Classification List', was circulated by the GATT Secretariat in 1991. It contains a list of relevant service 'sectors and subsectors', along with 'corresponding CPC' numbers - from the UN Provisional Product Classification - for each subsector. The ' 1993 Scheduling Guidelines' were set out in an 'Explanatory Note' issued by the Secretariat in 1993. 
alternative measure. The Appellate Body found that the measures were 'necessary': The United States had made a prima facie case showing of 'necessity' and Antigua had failed to identify any other alternative measures that might be 'reasonably available'. With respect to the Article XIV(c) defence, the Appellate Body reversed the Panel due to its erroneous 'necessity' analysis and declined to make its own findings on the issue.

The Appellate Body modified the Panel's finding with respect to the chapeau of Article XIV. The Appellate Body reversed the Panel's finding that the measures did not meet the requirements of the chapeau because the United States had discriminated in the enforcement of those measures. However, the Appellate Body upheld the second ground upon which the Panel based its finding, namely that in the light of the Interstate Horseracing Act (which appeared to authorize domestic operators to engage in the remote supply of certain betting services), the United States had not demonstrated that its prohibitions on remote gambling applied to both foreign and domestic service suppliers, i.e. in a manner that did not constitute 'arbitrary and unjustifiable discrimination' within the meaning of the chapeau. 